\title{
Why Dissatisfied Mobile Subscribers Stay: Role of Service Use Experience, Commitment and Corporate Reputation
}

\author{
Joseph Mbawuni ${ }^{1}$, Simon Gyasi Nimako ${ }^{2}$ \\ ${ }^{1}$ Lecturer, Department of Accounting Studies Education, University of Education, Winneba, Ghana \\ ${ }^{2}$ Department of Management Studies Education, University of Education, Winneba, Ghana \\ Correspondence: Simon Gyasi Nimako, Department of Management Studies Education, University of Education, \\ Winneba, Ghana
}

Received: March 11, 2016

Accepted: March 28, 2016

Online Published: April 11, 2016

doi:10.5539/ibr.v9n6p112

URL: http://dx.doi.org/10.5539/ibr.v9n6p112

\begin{abstract}
This paper examines the extent to which service use experience, commitment and perceived positive corporate reputation affect loyalty behaviour of dissatisfied stayers in mobile telephony context. Drawing on relationship marketing and switching behaviour literature a conceptual framework was developed and tested using partial least square structural equation modelling. The proposed model was validated with data from 736 subscribers of six global providers of telecommunication services. Results show that commitment and corporate reputation have significantly positive influence on the loyalty of dissatisfied stayers. Generally, the present study confirms existing marketing literature that dissatisfied customers may not necessarily switch while making unique contribution on the influence of corporate reputation as a switching barrier for dissatisfied customers. The managerial and theoretical implications are discussed.
\end{abstract}

Keywords: dissatisfaction, stayers, switching, switching barrier, telecommunication

\section{Introduction}

Modern business organizations continue to purse customer-centric marketing strategies for retaining and building intimate long term relationship with profitable customers (Kotler \& Keller, 2012; Bolton, 2011; Gummesson, Kuusela, \& Närvänen, 2014; Jaakkola \& Alexander, 2014). Customers switch to competitors when firms are not able to retain them. This can be very expensive since losing customers can mean staying out of business. Dissatisfaction has been one of the main causes of consumer switching (Bansal et al., 2005; Nimako \& Ntim, 2015; Sathish, Kumar, \& Jeevanantham, 2011) while satisfaction also leads to customer loyalty (Helkkula, Kelleher, \& Pihlstro, 2012; Kotler \& Keller, 2012). However, there is some evidence in the literature that some dissatisfied customers may still remain loyalty to current service provider (Panther \& Farquhar 2004; Tseng \& Wang, 2013).

So far in the literature, results in past studies are limited to mostly firm-customer relationship factors that explain why dissatisfied customers still remain loyal to current service providers. Firm-customer relationship factors remain only one group of switching barriers (Bansal et al., 2005; Nimako \& Ntim, 2014). Firm-customer relationship factors include commitment, use of services, and trust (Jones, Motherbaugh \& Beatty, 2002; Keaveney \& Parthasarathy, 2001; White \& Yanamandram, 2004; Vazquez-Carrasco, \& Foxall, 2006). However, past research has failed to examine the effect of corporate reputation as a switching barrier that prevents dissatisfied customers to stay or remain loyal to their current service providers. Corporate reputation can be a powerful tool that could bind existing customers to their current service providers. Therefore, the main purpose is to assess the extent to which corporate reputation and firm-customer relationship factors influence loyalty of dissatisfied customers in mobile telecommunication industry, using Ghana mobile telecommunication industry (GMTI) as the research context. The present research will contribute to marketing literature on why dissatisfied customers stay in a relationship and not switch mobile telephony service providers.

\section{Literature Review}

\subsection{Switching Factors and Models}

According to Nimako (2012, p. 68) consumer switching behaviour (CSB) is defined as "Consumer switching behaviour is the process by which a consumer abandons his/her relationship with a current service/product provider and replaces it with a competitor partially or entirely for a given time period." Many factors cause consumers to switch services providers. To understand these switching factors, many switching models and theories have been developed to 
understand the switching antecedents and determinants in the extant marketing literature. Some of them are service quality, core service failure, price customer satisfaction/dissatisfaction and relationship factors (Keaveney, 1995; Lin, 2010; Lin \& Mattila, 2006; Nimako \& Ntim, 2014).

The Push-Pull-Mooring (PPM) model of service switching (Bansal et al. 2005) is widely adopted as a comprehensive model for understanding switching antecedents in many service contexts (Cheng et al., 2009; Hou et al., 2011; Ye \& Potter, 2011; Fu, 2011; Hsieh et al., 2012; Zhang et al. 2012). The PPM Theory is a human migration theory that attempts to explain the reasons why people move from one place of origin to another for a time period (Bansal et al. 2005). The theory posits that push effects are negative factors that force people to move away from their origin to another place. Push factors include unemployment, wars, loss of jobs, natural disasters, poverty (Lee, 1966; Moon, 1995). On the other hand, pull factors are positive factors that attract people to move to a new destination. Pull factors include better economic conditions, peaceful environment, better job opportunities, higher incomes, quality education, quality health care facilities, among others (Lee, 1966; Moon, 1995). These push and pull factors work together with the mooring factors. The mooring factors are a kind of moderating variables, and work to promote or discourage the potential migrants from leaving their origin to a new destination.



Figure 1. Push-Pull-Mooring (PPM) Migration Model of Service Switching (Bansal, Taylor, \& James, 2005)

Several past studies have attempted to apply Bansal et al.'s (2005) model of CSB because it provides a useful theoretical model for understanding CSB in marketing and other business-related disciplines (Cheng et al., 2009; Hou et al., 2011; Ye \& Potter, 2011; Fu, 2011; Hsieh et al., 2012; Zhang et al. 2012). Nimako and Ntim (2014) have recently extended the PPM service model of Bansal et al.'s (2005) to develop a PP3M model for understanding CSB telecommunication industry.

\subsection{Determinants of Loyalty of Dissatisfied Stayers}

Empirical research shows that some satisfied customers may still switch and/or not be loyal (e.g., Jones \& Sasser, 1995; Jung \& Yoon, 2012; White \& Yanamandram, 2004) while dissatisfied customers may not necessarily switch (e.g., Patterson \& Smith, 2003; Panther \& Farquhar 2004; Tseng \& Wang, 2013) but remain loyal to a service provider. The main reasons for this situation identified in the literature are positive firm-customer relationship factors and switching barriers that deter customers from discontinuing a business relationship in both the B2C context (Jones, Motherbaugh \& Beatty, 2002; Keaveney \& Parthasarathy, 2001; Patterson \& Smith, 2003). There is, however, very limited empirical evidence on the influence of other constructs such as corporate reputation in explaining the loyalty of dissatisfied stayers. This study attempts to contribute to filling this gap in the extant marketing literature.

\subsection{Conceptual Framework and Hypotheses}

Drawing from relationship marketing and consumer switching behaviour literature, a research model is developed as shown in Figure 2. From the research model, there are two relationship factors, service experience (use of services) and commitment, in addition to corporate reputation, are hypothesized to influence loyalty of dissatisfied stayers.

\subsubsection{Service Use Experience and Loyalty of Dissatisfied Stayers}

Service experience is a relationship factor that relates to the use of services by customers of product/service (Nimako \& Ntim, 2014). Customers' use of service describes the extent of frequency of use (relationship depth), variety of services used (relationship width), length of service experience (relationship length) (Lopez et al., 2006; Nimako \& Ntim, 2014). Generally, the consumers use frequently a varieties of service providers' services for a long time, the more they involved with the service providers. This can service as a structural relationship bond between the customer and service provider. This could also act as a switching barrier even some level of dissatisfaction exists. Several studies have found that these relationship factors are strong reasons why dissatisfied customers may not discontinue a relationship with 
service providers many service contexts (e.g. Jones et al., 2002; Keaveney \& Parthasarathy, 2001; Patterson \& Smith, 2003; Panther \& Farquhar 2004). This, therefore, leads the hypothesis that:

H1: Service experience (SXP) will have significantly positive influence on loyalty of dissatisfied stayers. Specifically, the stronger the service experience, the stronger will be the loyalty of dissatisfied mobile subscribers.

\subsubsection{Commitment and Loyalty of Dissatisfied Stayers}

Commitment has been defined as an attitude that reflects the desire to maintain a valued relationship (Moorman, Zaltman, \& Deshpande, 1992). Commitment is an essential appraisal mechanism by which a customer determines whether or not to have a long term relationship with a brand or firm and for how long (Bansal et al., 2004). Commitment to service provider is one of the relationship marketing constructs that has been found to be antecedent to switching intentions and behaviour (Bansal et al., 2004; Nimako \& Ntim, 2014), and act in various ways as relationship bonds (Berry, 1995; Berry and Parasuraman, 1991; Chiu et al., 2005), and induces brand attachment and love (Batra et al., 2012; Carroll and Ahuvia, 2006). Previous studies have established that when consumer commitment service provider is strong, it strengthens the relationship between a firm and its customers in many research contexts (Batra et al., 2012; Bansal et al., 2004; Morgan and Hunt, 1994; Nimako \& Ntim, 2014). Thus, a consumer's commitment to a service provider could increase the switching cost in many service contexts (Bansal et al., 2004). Therefore, as a result of the strength of commitment to a service provider, some dissatisfied consumers are likely to remain loyal to current service providers and not switch to competitors. This leads the hypotheses that:

H2: Consumers' Commitment to a service provider will have a positive influence on loyalty of dissatisfied stayers. Specifically, the stronger the commitment the stronger will be the loyalty of dissatisfied stayers to an existing service provider.

\subsubsection{Corporate Reputation and Loyalty of Dissatisfied Stayers}

Corporate reputation refers to a company's status among customers' employees and other stakeholders compared to its rivals (Ettenson, \& Knowles, 2008; Fombrum, 1996). Good reputation pays. Corporate reputation has been found to be a strong switching factor in many service contexts (Gerrard and Cunningham, 2004; Clemes et. al., 2007; Nimako \& Ntim 2014). It has been found that consumer are interested in good reputation of their service providers and factor reputation in evaluating service providers in B2C contexts (Bansal et al., 2005; Nimako, 2012b). In spite of the importance firm reputation in the extant marketing literature, past studies have failed to conceptualise firm reputation as a switching cost or barrier that could influence existing dissatisfied customer to stay with a current service provider. This study, therefore, proposes that a firm's good or positive corporate reputation can influence consumers to stay or become loyal even when they are dissatisfied. Therefore, this study hypothesises that:

H3: Perceived firm reputation will positively influence loyalty of dissatisfied stayers. Specifically, the stronger the perceived firm reputation, the stronger will be consumers loyalty to current service provider.

\section{Methodology}

\subsection{Population and Sampling}

This study was part of a larger study conducted, which had a population of 27,244,579 individual subscribers as of April, 2013 (NCA, 2013) from all the six global operators in Ghana's mobile telecommunication industry (GMTI). A survey was conducted in three major cities/parts of Ghana and yielded a usable 736 questionnaire returned for final data analysis.

\subsection{Research Instrument}

A self-administered, structured questionnaire was developed from the literature reviewed and preliminary focus group interviews conducted by the researchers. In all, the measurement items derived from previous studies were modified within the context of the mobile telecom service. The Likert scale was used ranging from strongly disagree to strongly agree, coded 1 to 5 respectively to measure key constructs in the model, which are: service use experience, commitment, firm reputation and loyalty, and customer satisfaction. Finally, the questionnaire also contained respondents' demographic data: gender, age, and education.

\section{Results}

This section presents results on the effect of service experience, commitment and corporate reputation on the loyalty of 162 dissatisfied stayers (non-switchers). To identify dissatisfied stayers, the overall satisfaction item was used to categorise respondents into satisfiers (4 and 5 responses) and dissatisfiers (1-2 responses). Then one switching intentions item was used to categorise the sample into considerers of switching ( 4 and 5 responses) and non-considerers of switching ( 1 and 2 responses). In all there were 162 dissatisfied but non-considerers of switching customers. 


\subsection{Respondents' Demographic Characteristics}

The results show that the males were $67.7 \%$ and the females were $32.3 \%$. In terms of age, $20.7 \%$ of them were below 25 years, $67.3 \%$ of them were between the ages of $25-36$ years, $11.4 \%$ were between 37 and 50 years, and $0.6 \%$ were 51 years and above. Thus majority of the respondents were economically active. In terms of education, $58.7 \%$ of them have higher education, 5\% had Senior High School (SHS) education, 33\% had post-SHS education, while 3\% had other forms of education. For their income levels, $33.5 \%$ of the respondents earned monthly income up to US\$250, while $43.9 \%$ earned between US\$ 250 and US\$ 500, 6.5\% earned monthly income above US\$ 500. This shows that most of the respondents were relatively low income earners.

$61.7 \%$ of the respondents were married people, $36 \%$ were single and $2 \%$ of them were in other marital groups. $9 \%$ of them had been mobile customers for less than five years, $56.1 \%$ of them had between five and nine years of customer relationship, 26\% of them had between 15 and 19 years of customer relationship with their mobile service providers and about $8 \%$ of them had been mobile customers for over 20 years. Generally, this indicates that most of the respondents had considerable experience in the use of mobile network services. Out of the 736 respondents, $5.4 \%$ of them use Expresso services $(n=40), 7.5 \%$ of them use Glo services $(n=55), 13.9 \%$ of them use Airtel service $(n=102), 8.3 \%$ use Tigo service $(n=61), 24 \%$ of them use Vodafone services $(n=177)$ and $40.9 \%$ of them use MTN $(n=301)$ services.

\subsection{Structural Model Analysis}

Data was analysed using partial least squares (PLS), specifically, SmartPLS 2.0 (Ringle et al., 2005) to perform structural equation modelling (SEM). PLS-SEM was deemed most appropriate, mainly because of the nested nature of the proposed models, which also had formative indicators that could be handled easily in PLS in terms of model identification compared to CB-SEM (Chin, 2010). 500 bootstrapping samples were run to get t-values to determine the significance of regression weights. Using Yamane's (1967) formula, the sample of 736 was statistically adequate because it is far above what has been recommended as a rule of thumb for detecting small interaction effects, i.e., a minimum ratio of ten cases per parameter estimated (Bentler \& Chou, 1988; MacCallum et al., 2006). A two-stage analysis was followed as recommended for SEM in general (Anderson and Gerbing, 1988) and PLS-SEM in particular (Chin, 2010).

\subsection{Assessing Reliability and Validity}

Second, the research model was estimated using SmartPLS 2.0 (Ringle et al., 2005). The adequacy of reliability and validity of research constructs and measurement indicators were examined with 500 bootstrap samples. Moreover at the construct level, the results of the reliability and validity of reflective indicators or constructs for sample are presented in the Tables 2 and 3. From these tables the results indicate that there is good construct validity for all constructs in the model for the two groups given that CRs, AVEs, CAs are all above their recommended levels (Hair et al., 2010).

Table 1 and 2 Reliability and validity for dissatisfied stayers.

Table 1 . Reliability and discriminant validity

\begin{tabular}{lrrrcccc}
\hline & CMT & LTY & REP & SXP & AVE & CR & CA \\
\hline CMT & 0.90 & & & & 0.81 & 0.93 & 0.88 \\
LTY & 0.67 & 0.91 & & & 0.83 & 0.90 & 0.79 \\
REP & 0.61 & 0.51 & 0.84 & & 0.70 & 0.87 & 0.79 \\
SXP & -0.25 & -0.15 & -0.25 & 0.73 & 0.53 & 0.59 & 0.68 \\
\hline
\end{tabular}

Table 2. Cross loading of measurement items

\begin{tabular}{cllll}
\hline & CMT & LTY & REP & RLS \\
CMT1 & 0.90 & 0.59 & 0.48 & -0.17 \\
CMT2 & 0.93 & 0.60 & 0.54 & -0.21 \\
CMT3 & 0.88 & 0.63 & 0.61 & -0.29 \\
LTY1 & 0.62 & 0.91 & 0.45 & -0.13 \\
LTY2 & 0.60 & 0.91 & 0.47 & -0.14 \\
REP1 & 0.57 & 0.44 & 0.87 & -0.21 \\
REP2 & 0.39 & 0.32 & 0.76 & -0.12 \\
REP3 & 0.54 & 0.48 & 0.88 & -0.27 \\
SXP 1 & -0.10 & -0.08 & 0.03 & 0.52 \\
SXP2 & -0.21 & -0.11 & -0.31 & 0.76 \\
\hline
\end{tabular}

Notes: Dissatisfied stayers ( $\mathrm{n}=162)$, AVE - Average variance extracted; Benchmarks Hair et al, 2010): AVEs $>=0.50$, Composite reliability $>=0.70$, Cronbach alpha $>=0.70$, Square roots of Average variance extracted in the diagonal, Corporate reputation (REP), Commitment (CMT), Service Use Experience (SXP), Dependent variable: Loyalty (LTY), 


\subsection{Assessment of Structural (Inner) Model}

The results of the structural model for the proposed relationships are presented in Table 3 and Figure 1.

Table 3. Parameter estimates and model's predictive power (dissatisfied stayers)

\begin{tabular}{llcccll}
\hline & & \multicolumn{2}{c}{ Dissatisfied stayers $(\mathbf{n}=\mathbf{1 6 2})$} & & \multicolumn{2}{c}{$\begin{array}{l}\text { Predictive power } \\
\text { Hyp }\end{array}$} \\
Paths & Weight & t-value & P-value & Remarks & Predictive rel. $\left(\mathbf{Q}^{2}\right)$ \\
\hline H1 & SXP -> LTY & 0.037 & 1.035 & 0.302 & Not significant & -0.373 \\
H2 & CMT -> LTY & 0.581 & 14.351 & 0.000 & Significant & 0.598 \\
H3 & REP -> LTY & 0.163 & 3.861 & 0.000 & Significant & 0.404 \\
& $\mathrm{R}^{2}$ (LTY) & 0.46 & & & & 0.424 \\
\hline
\end{tabular}

Note: $* * *$ Significant at $0.000, * *$ Significant at $0.01, *$ Significant at 0.05 ;

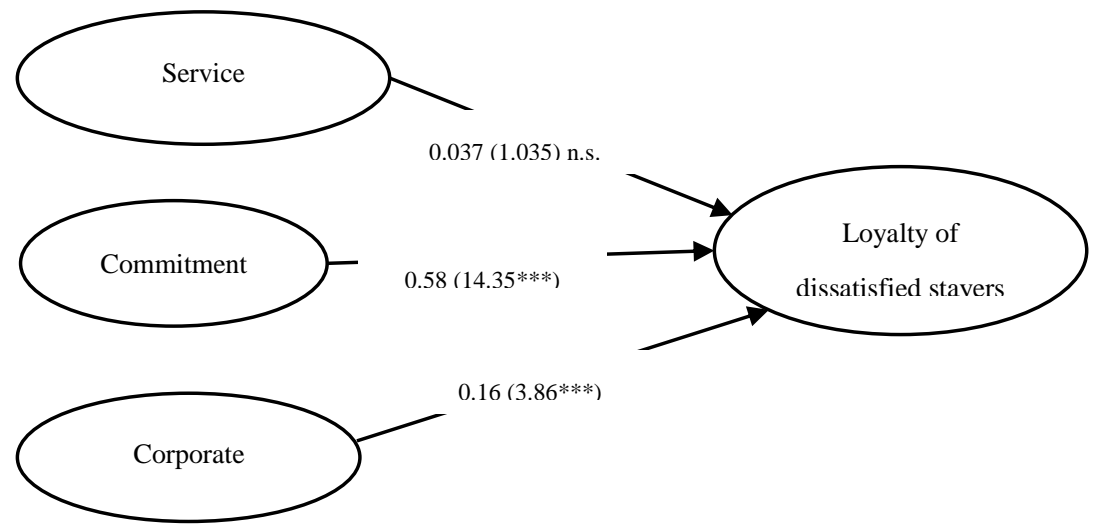

Figure 2. Research model and hypotheses

From Table 3 and Figure 1, the model predicted about 46\% loyalty of dissatisfied-stayers. The results show that commitment has a positive influence on loyalty of about $58 \%$, supporting hypothesis H1. Service use experience makes positive but non-significant relationship on loyalty of dissatisfied customers by $3.7 \%$, disproving hypothesis $\mathrm{H} 2$. Positive corporate reputation positively influences loyalty by $16 \%$, confirming hypothesis $\mathrm{H} 3$. Thus, generally, neither negative factors at the service provider service delivery (push factors) nor positive competitor factors such as attractiveness of competitor offering and reputation quality (pull factors) influence customer loyalty.

\section{Discussion}

This study aimed at assessing the extent to which service use experience, commitment and perceived positive corporate reputation affect loyalty behaviour of dissatisfied stayers in mobile telephony context. The results show that, among the three, the strongest factor that explains the loyalty of dissatisfied stayers is commitment, which explains as much as $58 \%$ of loyalty of this group and make a large effect size of 0.37 (Cohen, 1988). This is followed by corporate reputation. Generally, the present study confirms existing marketing literature that dissatisfied customers may not necessarily switch (e.g., Patterson \& Smith, 2003; Panther \& Farquhar 2004; Tseng \& Wang, 2013) but remain loyal to a service provider. In the present study found that commitment and reputation factors could explains loyalty behaviour among dissatisfied non-switchers. This finding confirms many past studies in the marketing literature, which also identified positive firm-customer relationship factors as fundamental reason for some dissatisfied customers not discontinuing a business relationship both in the B2C context (Jones et al., 2002; Keaveney \& Parthasarathy, 2001; Nimako \& Ntim, 2014; Patterson \& Smith, 2003). This implies that in the mobile telecom industry in developing economies, the hypothesis is true that, in spite of some level of dissatisfaction that may occur with a current service provider's service delivery, mobile subscribers are likely to resist switching to new service providers and remain loyal to current provider if a strong firm-customer relationship commitment exist, coupled with positive firm reputation (Bell et al., 2005; Lopez et al., 2006).

\subsection{Contribution to Theory}

The present research contributes to marketing theory on why dissatisfied customers stay in a relationship with current service providers in two ways. First, this study provides empirical evidence to confirm the influence relationship marketing factors such as consumer use of service experience and commitment to service provider influence the loyalty of dissatisfied stayers in B2C context. Theoretically, this finding lends strong support to existing marketing literature (e.g. Jones \& Sasser, 1995; Patterson \& Smith, 2003; Nimako \& Ntim, 2014) that at certain levels of dissatisfaction with current service provider may not negatively affect consumers' loyalty to current service providers in general and in mobile telecommunication industry in particular. 
Second, this study is among the first to provide empirical evidence on the extent to which corporate reputation of existing service provider could act as a switching barrier to influence dissatisfied customers to be loyal in B2C context. The findings show that positive corporate reputation can be a significant switching barrier to switching and induce loyalty of dissatisfied stayers, lending strong support to existing marketing literature (e.g. Tseng \& Wang, 2013; Vazquez-Carrasco, \& Foxall, 2006; Nimako \& Ntim, 2014).

\subsection{Managerial Implications}

The findings means that marketers in mobile telecom industry can achieve loyalty of dissatisfied stayers by developing marketing strategies that focus on building commitment and positive corporate reputation. This will enable consumers to enjoy and delight in the use of the firm's services, and build strong emotional and structural bonds with service provider (Bansal \& Taylor 1999; Bansal et al., 2004). The long-term effects of these marketing strategies are strong brand attachment and love (Carroll \& Ahuvia, 2006; Bagozzi, Batra, \& Ahuvia, 2013); increased repeat business and positive recommendation of service provider, increased consumer spending for firm's services (wallet share), consumer loyalty, and weaker switching intentions of customers (Sheth \& Parvatiyar, 1995; Batra et al., 2012; Chiu et al., 2005).

\subsection{Limitations and Conclusion}

This study is limited to the context of GMTI and that the model should be extended to other developing country research contexts to improve upon the generalizability of the findings. In summary, drawing on the relationship marketing and consumer switching behaviour literature, this study has provided empirical knowledge to scholars and practitioners regarding the influence of service use experience, commitment and corporate reputation on loyalty of dissatisfied stayers in developing country mobile telecom industry. The present research contributes to marketing and information systems literature on why dissatisfied customers stay in a relationship and not switch.

\section{References}

Bansal, H. S., \& Taylor, S. F. (1999). The service provider switching model (SPSM): A model of consumer switching behavior in the services industry. Journal of Service Research, 21, 200-218. http://dx.doi.org/10.1177/109467059922007

Bansal, H. S., Irving, P. G., \& Taylor, S. F. (2004). A three component model of customer commitment to service provider. Journal of the Academy of Marketing Science, 32(3), 234-250. http://dx.doi.org/10.1177/0092070304263332

Bansal, H. S., Taylor, S. F., \& James, Y. (2005). "Migrating” to New Service Providers: Toward a Unifying Framework of Consumers' Switching Behaviors. Journal of the Academy of Marketing Science, 33(1), 96-115. http://dx.doi.org/10.1177/0092070304267928.

Bogue, D. J. (1977). A Migrants-Eye View of the Costs and Benefits of Migration to a Metropolis. In Internal Migration: A Comparative Perspective. New York: Academic Press, 167-182.

Cheng, Z., Yang, Y., \& John, L. (2009). Cyber Migration: An Empirical Investigation onFactors that Affect Users' Switching Intentions in Social Networking Sites Proceedings of the $42^{\text {nd }}$ Hawaii International Conference on System Sciences, 200.

Chin, W. (2010). How to write up and report PLS analyses. In: EspositoVinzi V, Chin W.W, Henseler J, Wang H (eds) Handbook of partial least squares: concepts, methods and applications. Springer Heidelberg, 655-690. http://dx.doi.org/10.1007/978-3-540-32827-8_29

Clemes, M. D., Gan, C., \& Zheng, L. Y. (2007). Customer switching behaviour in the New Zealand banking industry. Banks and Bank Systems, 2(4), 50-65.

Edvardsson, B., \& Roos, I. (2003). Customer Complaints and Switching Behavior- A Study of Relationship Dynamics in a Telecommunication Company. Journal of Relationship Marketing, 2(1/2), 43-68. http://dx.doi.org/10.1300/J366v02n01_04

Ettenson, R., \& Knowles J. (2008). Don't Confuse Reputation With Brand. MIT Sloan Management Review, 49(2), 18-21. 17.

Fombrum, C. H. (1996). Reputation: realizing value from the corporate image. Harvard Business School Press.

$\mathrm{Fu}$, J. R. (2011). Understanding career commitment of IT professionals: Perspectives of push-pull mooring framework and investment model. International Journal of Information Management, 31(3), 279-293. http://dx.doi.org/10.1016/j.ijinfomgt.2010.08.008

Gerrard, P., \& Cunningham, J. B. (2004). Consumer switching behavior in the Asian banking market. Journal of Services Marketing, 18, 215-223. http://dx.doi.org/10.1108/08876040410536512 
Gro"nroos, C. (2001). The Perceived Quality Concept: a mistake? Managing Service Quality 11(3), 150-152. http://dx.doi.org/10.1108/09604520110393386

Gummesson, E., Kuusela, H., \& Närvänen, E. (2014). Reinventing marketing strategy by recasting supplier/customer roles. Journal of Service Management, 25(2), 228-240. http://dx.doi.org/10.1108/JOSM-01-2014-0031

Helkkula, A., Kelleher, C., \& Pihlstro, M. M. (2012). Characterizing value as an experience: implications for service researchers and managers. Journal of Service Research, 15 (1), 59-75. http://dx.doi.org/10.1177/1094670511426897

Hou, A. C. Y., Chern, C. C., Chen, H. G., \& Chen, Y. C. (2011). Migrating to a New Virtual World': Exploring MMPORG Switching through Human Migration Theory. Computers in Human Behavior, 27(5), 1892-1903. http://dx.doi.org/10.1016/j.chb.2011.04.013

Hsieh, J. K., Hsieh, Y. C., Chiu, H. C., \& Feng, Y. C. (2012). Post-Adoption Switching Behavior for Online Service Substitutes: A Perspective of the Push-Pull-Mooring Framework. Computers in Human Behavior, 28, 1912-1920. http://dx.doi.org/10.1016/j.chb.2012.05.010

Jaakkola, E., \& Alexander, M. (2014). The Role of Customer Engagement Behavior in Value Co Creation A Service System Perspective. Journal of Service Research, 1- 15. http://dx.doi.org/1094670514529187.

Keaveney, S. M. (1995). Customer switching behavior in service industries: An exploratory study. Journal of Marketing, 50(2), 71-82. http://dx.doi.org/10.2307/1252074

Kotler, P., \& Keller, K. L. (2012). Marketing Management 14th Edition, Upper Saddle River, NJ: Prentice Hall

Lam, T., \& Hsu, C. H. C. (2006) Predicting behavioral intention of choosing a travel destination. Tourism Management, 27, 589-599. http://dx.doi.org/10.1016/j.tourman.2005.02.003

Lee, E. S. (1966). A Theory of Migration. Demography, 3 (1), 47-57. http://dx.doi.org/10.2307/2060063

Lin, I. Y. H., \& Mattila, A. S. (2006) Understanding restaurant switching behavior from a cultural perspective. Journal of Hospitality \& Tourism Research, 31, 3-15. http://dx.doi.org/10.1177/1096348005284266

Lopez J. P. M., Redondo Y. P., \& Olivan, F. J. S. (2006). The impact of customer relationship characteristics on customer switching behaviour. Difference between switchers and stayers, Managing Service Quality, 16(6), 556574. http://dx.doi.org/10.1108/09604520610711909

Manrai, L. A., \& Manrai, A. K. (2007). A Field Study of Consumers' Switching Behavior for Bank Services. Journal of Retailing and Consumer Services, 14(3), 208- 217. http://dx.doi.org/10.1016/j.jretconser.2006.09.005

Moon, B. (1995). Paradigm in Migration Research: Exploring 'Moorings' as a Schema. Progress in Human Geography, 19, 504-524. http://dx.doi.org/10.1177/030913259501900404

National Communication Authority (2013). Telecom voice subscription trends. Retrievedfrom http://www.nca.org.gh/downloads/Telecom_Voice_Subscription_July_2013.pdf on Aug. 20, 2013

Nimako, G. S., Azumah, K. F., Donkor, F., \&Adu-Brobbey, V. (2010). Overall Customer Satisfaction in Ghana's Mobile Telecommunication Networks: Implications for Management and Policy. African Technology Development Forum, 7(3/4), 35-49.

Nimako, S. G. (2012). Linking quality, satisfaction and behaviour intentions in Ghana's mobile telecommunication industry. Eur. J. Bus. Manag., 4(7), 1-17.

Nimako, S. G., \& Ntim, B. A. (2015). Modelling the Antecedents and Consequence of Consumer Switching Intentions in Ghana Mobile Telecommunication Industry. International Journal of Business and Emerging Markets, 7(1), 37-75. http://dx.doi.org/10.1504/IJBEM.2015.066093.

Ringle, C. M., Wende, S., \& Will, S. (2005). SmartPLS 2.0 (M3) Beta. Hamburg, http://www.smartpls.de

Sathish M., Kumas K. S., \& Jeevanantham, K. J. V. (2011). A study on consumer switching behaviour in cellular service provider: A study with reference to Chennai, Far East Journal of Psychology and Business, 2(2), 71-81.

Seo, D., Ranganathan, C., \& Babad, Y. (2008). Two-level model of customer retention in the US mobile telecommunications service market. Telecommunications Policy, 32(3), 182-196.

http://dx.doi.org/10.1016/j.telpol.2007.09.004

Yamane, T. (1967). Statistics: an introductory analysis. New York: Harper and Row. 
Ye, C., \& Potter, R. (2011). The Role of Habit in Post-Adoption Switching of Personal Information Technologies: An Empirical Investigation. Communications of the Association for Information Systems, 28(1), 585-610. Available at: http://aisel.aisnet.org/cais/vol28/iss1/35

Zhang, K. Z. K., Cheung, C. M. K., \& Lee, M. K. O. (2012). Online service switching behavior: The case of blog service providers. Journal of Electronic Commerce Research, 13(3), 184 -197.

\section{Copyrights}

Copyright for this article is retained by the author(s), with first publication rights granted to the journal.

This is an open-access article distributed under the terms and conditions of the Creative Commons Attribution license (http://creativecommons.org/licenses/by/3.0/). 